\title{
Quantitative and Qualitative Study of Diatoms Around Fifh Cage in the Southern Basin of the Caspian Sea
}

\author{
Fatemeh Sadat Tahami* and Alireza Keyhan Sani \\ Caspian Sea Ecology Research Center (CSERC), Iranian Fisheries Science Research Institute (IFSRI), Agricultural Research, \\ Education and Extension Organization (AREEO), Iran
}

*Corresponding author: Fatemeh Sadat Tahami, Caspian Sea Ecology Research Center (CSERC), Iranian Fisheries Science Research Institute (IFSRI), Agricultural Research, Education and Extension Organization (AREEO), Iran

\section{ARTICLE INFO}

Received: 幽 April 07, 2021

Published: 绊 April 22, 2021

Citation: Fatemeh Sadat Tahami, Alireza Keyhan Sani. Quantitative and Qualitative Study of Diatoms Around Fifh Cage in the Southern Basin of the Caspian Sea. Biomed J Sci \& Tech Res 35(2)-2021. BJSTR. MS.ID.005678.

Keywords: Diatoms; Salmon; Breeding Site; Nowshahr; South Caspian Sea

\section{ABSTRACT}

The presence of abundant nutrients can pose risks such as changes in the dynamics of diatom communities, as well as allowing the overgrowth of harmful species, the possibility of non-native and invasive aquatic growth in the Caspian Sea and vice versa, reducing or eliminating some species and algal blooms. It may be dangerous for breeding. Therefore, the study of diatom communities and their interaction with fish farming is necessary and important. Therefore, in this study, the waters around the cage and also before and after the fish farming period in the cage were sampled and identified based on the presented methods. Fish breeding cages are located in the southern basin of the Caspian Sea at a depth of 30 meters from the sea shore. North, east, south and west of the cage were sampled from distances next to the fish breeding cage (shade), $200 \mathrm{~m}$ from the cage and $1000 \mathrm{~m}$ from the cage at depths of surface, middle and depth $(30 \mathrm{~m})$. In total, a total of 39 species of 20 genera of diatoms were identified during the sampling performed during four periods which include Actinocyclus(2 species), Chaetoceros (5 species), Cocconeis (1 species), Coscinodiscus (3 species), Cyclotella(1 species), Cymbella(1 species), Dactyliosolen(1 species), Diatoma (1 species), Diploneis(1 species), Gyrosigma (3 species), Hantzschia (1 species), Hyalodiscus (1 species), Navicula (3 species), Nitzschia(7 species), Pseudonitzschia (1 species), Pleurosigma (1 species), Rhizosolenia (2 species), Skeletonema (2 species), Talassiosira (1 species), Thalassionema (1 species). The highest density of diatoms was in the pre-breeding period and the highest density was observed in the western region $(9747 \pm 1562 \times 104$ per cubic meters). At the beginning of the breeding period, the highest diatomaceous earth density was observed in the east $(9454 \pm 864 \times 104$ per cubic meters $)$ and then in the middle of the breeding period, the density decreased significantly in all areas and then at the end of the breeding period, the diatomaceous earth density increased again.

Changes can be affected by environmental conditions. Which is one of the most important factors of seasonal changes that can affect the air temperature, river inflows and thus increase nutrients, water flows and as a result of salinity changes and river inflows. Salinity as well as excretion of feces and food not eaten by fish. Also, the highest density before the growing period and in the deep layer was due to low water temperature, which is due to the cold-loving nature of this branch $(\mathrm{P}<0.05)$. While the lowest density was in the middle of the rearing period, which may be due to the impact of salmon farming ecosystems in cages. Also, the highest density before the growing period and in the deep layer was due to low water temperature, which is due to the cold-loving nature of this branch $(\mathrm{P}<0.05)$. While the lowest density was in the middle of the rearing period, which may be due to the impact of salmon farming ecosystems in cages. 


\section{Introduction}

The success of fish farming in cages depends entirely on the proper quality of the water around the cage, and the farmer must strive to minimize the environmental pressures on the fish. One of the important factors that create and intensify environmental pressures on cages is the presence of abundant nutrients that can pose risks such as dynamic changes in biological communities such as diatoms, allowing overgrowth of harmful species, the possibility of non-native and invasive aquatic growth (Caspian Sea) [1] and reduce or eliminate some species as well as algal blooms [2], which can sometimes be dangerous for breeding. Therefore, the study of diatom communities and their interaction with fish farming is necessary and important. Therefore, in this study, the waters around the cage and before and after the period of fish farming in the cage were sampled and identified based on the proposed methods. Diatoms are diatomaceous plants of the algal group. Diatoms are tiny single-celled algae covered by thin, glassy boxes. Diatoms also live in freshwater and saline soils. The color of all diatoms is yellowish, because one type of yellow pigment covers the green color of chlorophyll, and diatoms reproduce by dual division of cells.

Diatoms are a group of autotrophic primates and contain chloroplasts. This type of beginning has two shells, small and large, one of which has a larger raduse than the other, and the smaller shell is placed inside the larger shell. During asexual reproduction, the two shells separate, and each piece becomes an independent organism, forming a complementary shell. After several generations of asexual reproduction, these organisms are no longer able to reproduce this type and form gametes. Diatoms are valuable markers for studying the environmental conditions of water. They respond quickly to physical, chemical, and biological changes in water, such as changes in temperature, food concentration, and the number of consumers. Each diatom species lives in a specific habitat. Therefore, they form diverse communities with different frequencies in different ecosystems [3] and the high diversity of diatoms leads to stronger statistical interpretations in model inference. Also, the possibility of identifying samples up to the species level increases the importance and accuracy of their use as a biological indicator. On the other hand, diatoms have the shortest life cycle compared to other biological indicators such as benthic invertebrates, aquatic plants and fish, and also reproduce by dividing in 20 minutes, both at the time of increasing water pollution and the deterioration of the aquatic ecosystem. They reproduce rapidly and their number increases. Therefore, these species are considered as indicators of infection and invasion. Diatoms are present in most aquatic ecosystems. Therefore, they can be sampled in all seasons. The cell wall structure of diatoms, a two-part frostol, is well preserved in sediments. Therefore, they can be used continuously to study habitat history [4].

\section{Materials and Methods}

Fish breeding cages are located in the southern basin of the Caspian Sea at a depth of 30 meters from the sea shore. North, east, south and west of the cage were sampled from the distances next to the fish breeding cage (shade), $200 \mathrm{~m}$ from the cage and $1000 \mathrm{~m}$ from the cage at depths, middle and depth (30 meter). Samoling of each station was performed from three depths: surface, middle and depth. Then, the samples were immediately fixed at the sampling site with $4 \%$ formalin (fix) and station specifications and sampling time and translated to the plank tonology laboratory of Caspian Sea Ecology Research Institute in glass containers with a volume of $500 \mathrm{ml}$. The samples were kept in the laboratory in the dark for 10 days to completely precipitate. The upper layer of water or supernatant, which did not contain any plankton, was then drained with a special siphon. The rest of the samples were centrifuged in several stages for 5 minutes (Labofuge 200 model at $3000 \mathrm{rpm}$ ) to reach a final sample volume of $25-3 \mathrm{ml}$. Samples for counting were placed on lined slides by a pipette with a volume of $0.1 \mathrm{~cm} 3$ [5]. After centrifugation, the samples were homogenized and stained with a few drops of eosin and then identified and examined under a microscope at 10x, 20x and 40x magnification [5-9]. At this stage, it is a qualitative study and only knowing their limits is important so that if it is too much for the counting stage, it can be diluted or concentrated. In quantitative examination of the samples, after determining the dilution or concentration in the qualitative stage, the sample was precipitated for 24 hours and then using a piston pipette, $0.1 \mathrm{ml}$ of the sample was removed and stained using eosin and using and then, it was identified under a microscope and the number and then the density per cubic meter were counted.

\section{Location of the Study Area}

The exact position of stations were determined using a satellite positioning device (GPS) and recorded. Longitude is $31^{\prime} 15^{\circ} 51 \mathrm{E}$ and latitude is $42^{\prime} 43^{\circ} 36 \mathrm{~N}$.

\section{Statistical Analysis}

After the experiments, the data were recorded in the relevant lists. Then the obtained data were entered in Excel statistical program and the relevant calculations were performed and graphs were drawn. Mean, standard deviation, amplitude, variance and error deviation were calculated in SPSS statistical program, version 13. This study gives the mean with standard error ( \pm SE) . Also, in order to analyze the variance and compare the data in sampling, SPSS statistical program was analyzed by analysis of variance and ANOVA was compared by Duncan test. 


\section{Results}

In this study, a total of 40 species from 20 genera of diatoms were identified. Commencement of breeding activities 24 species of diatoms were Identified (List 1) (Figure 1).

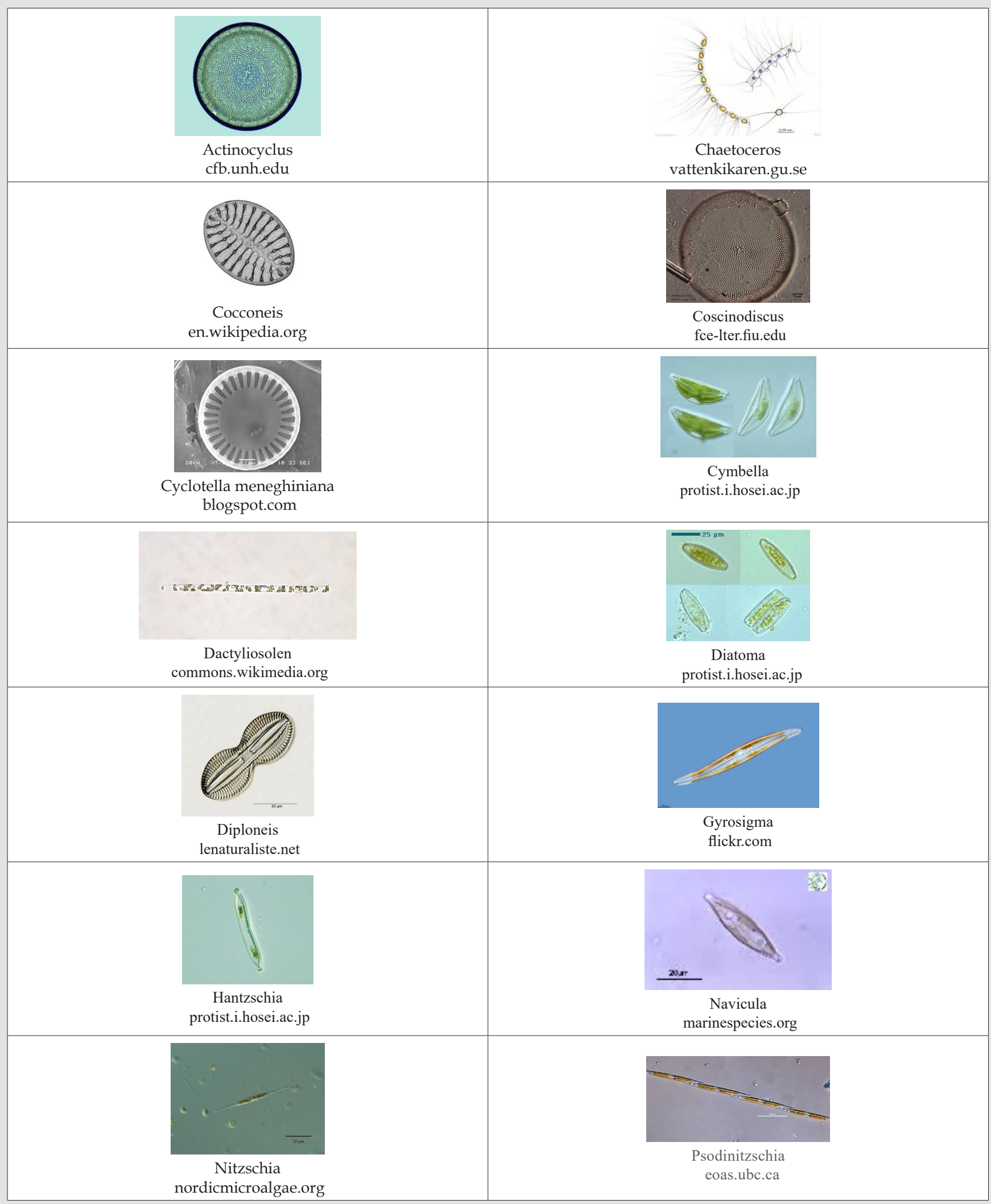




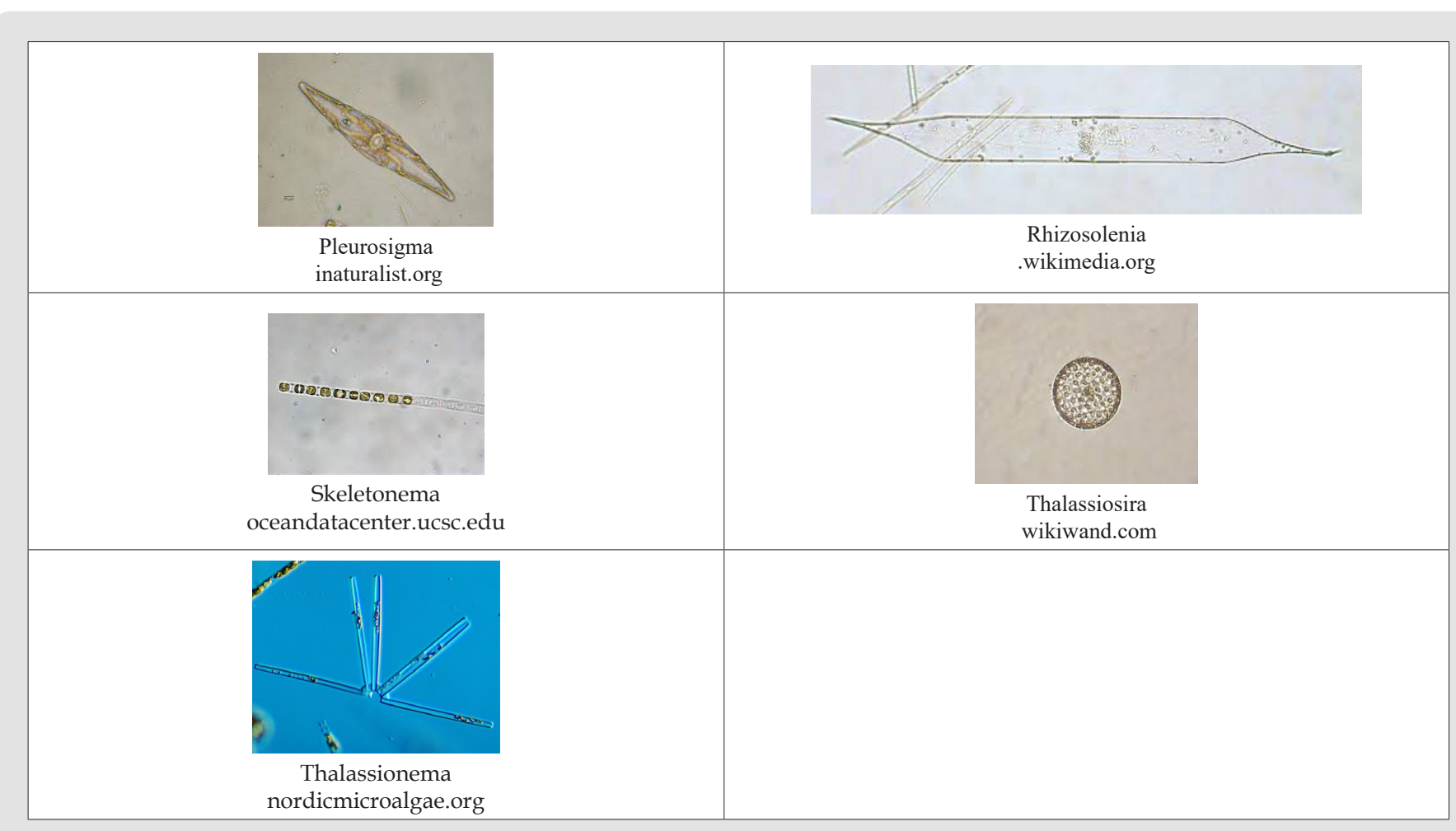

Figure 1: Figures of identified Genuses of diatom branch in different sampling periods around the cage.

\section{Chechlist 1}

Checklist of identified species of diatom branch in different sampling periods around the cage. According to (Chechlist 1), the highest number of diatoma species was observed at the end of the breeding period and the lowest species in the middle of the breeding period. Also, the number of diatoma species at the beginning of breeding has increased compared to the period before the breeding activity. The highest density of diatoms was in the pre-breeding period and the highest density was observed in the western region $(9747 \pm 1562 \times 104$ per cubic meters). At the beginning of the breeding period, the highest diatoma density was observed in the east $(9454 \pm 864 \times 104$ per cubic meters $)$ and then, in the middle of the breeding period, the density decreased significantly in all areas and then at the end of the breeding period, the diatomaceous earth density increased again (Table 1). The highest density of diatoms was observed in the deep layer before the breeding period and then the highest density was observed in the middle layer at the beginning of the breeding period and then in the middle of the breeding period the density of diatoms was observed in all three depths: middle, deep and deep. Then, in all depths, the density of diatom branches increased (Figure 2). Although the highest density was observed before the rearing period, the highest biomass was observed at the beginning of the rearing period and then in the middle of the rearing period, diatomaceous earth masses decreased significantly in all three depths: intermediate and deep. Continued (Figure 3).

Chechlist 1: Chechlist of identified species of diatom branch in different sampling periods around the cage.

\begin{tabular}{|c|c|c|c|c|c|}
\hline \multirow{2}{*}{ Genus } & Species & $\begin{array}{c}\text { Before the } \\
\text { Breeding Period }\end{array}$ & $\begin{array}{c}\text { Start of the } \\
\text { Breeding Period }\end{array}$ & $\begin{array}{c}\text { Mid- Breeding } \\
\text { Period }\end{array}$ & $\begin{array}{c}\text { End of the Breeding } \\
\text { Period }\end{array}$ \\
\hline \multirow{2}{*}{ Actinocyclus } & $\begin{array}{c}\text { Actinocyclus ehrenbergii } \\
\text { Actinocyclus paradoxus }\end{array}$ & & + & + \\
\hline \multirow{5}{*}{ Chaetoceros } & $\begin{array}{c}\text { Chaetoceros affinis } \\
\text { Chaetoceros convolutus } \\
\text { Chaetoceros percicus... }\end{array}$ & + & + & + \\
& $\begin{array}{c}\text { Chaetoceros peruvianus } \\
\text { Chaetoceros socialis }\end{array}$ & + & + & + \\
\hline Cocconeis & Cocconeis sp & + & + & + \\
\hline
\end{tabular}




\begin{tabular}{|c|c|c|c|c|c|}
\hline Coscinodiscus & $\begin{array}{c}\text { Coscinodiscus granii } \\
\text { Coscinodiscus jonesianus }\end{array}$ & + & + & & + \\
\hline Cyclotella & Cyclotella menenghiniana & + & + & + & + \\
\hline Cymbella & Cymbella sp. & & & & + \\
\hline Dactyliosolen & Dactyliosolen fragilissima & + & + & & \\
\hline Diatoma & Diatoma ochikii & & & + & \\
\hline Diploneis & Diploneis interrupta & & + & & \\
\hline Gyrosigma & $\begin{array}{l}\text { Gyrosigma attenuatum } \\
\text { Gyrosigma accominatum } \\
\text { Gyrosigma attenuatum }\end{array}$ & + & + & & $\begin{array}{l}+ \\
+ \\
\end{array}$ \\
\hline Hantzschia & Hantzschia sp. & & & & + \\
\hline Hyalodiscus & Hyalodiscus sphoerephorus & & + & & \\
\hline \multirow{3}{*}{ Navicula } & Navicula bombus & \multirow[t]{2}{*}{+} & & & \multirow{3}{*}{$\begin{array}{l}+ \\
+\end{array}$} \\
\hline & Naviculla sp2 & & & & \\
\hline & Navicula sp. & + & + & + & \\
\hline Nitzschia & $\begin{array}{c}\text { Nitzschia sp } \\
\text { Nitzschia acicularis } \\
\text { Nitzschia closterium } \\
\text { Nitzschia reversa } \\
\text { Nitzschia longissima } \\
\text { Nitzschia tenuirostris } \\
\text { Nitzschia hybrida }\end{array}$ & $\begin{array}{l}+ \\
+ \\
+\end{array}$ & $\begin{array}{l}+ \\
+\end{array}$ & $\begin{array}{l}+ \\
+ \\
+\end{array}$ & $\begin{array}{l}+ \\
+ \\
+ \\
+ \\
+ \\
+ \\
+\end{array}$ \\
\hline Pseudonitzschia & Pseudonitzschia seriata & + & + & + & + \\
\hline Pleurosigma & Pleurosigma elongatum & + & & + & \\
\hline Rhizosolenia & $\begin{array}{l}\text { Rhizosolenia calcaravis } \\
\text { Rhizosolenia fragilissima }\end{array}$ & $\begin{array}{l}+ \\
+\end{array}$ & $\begin{array}{l}+ \\
+\end{array}$ & & $\begin{array}{l}+ \\
+\end{array}$ \\
\hline Skeletonema & $\begin{array}{l}\text { Skeletonema costatum } \\
\text { Skeletonema subsalsum }\end{array}$ & + & $\begin{array}{l}+ \\
+ \\
\end{array}$ & & $\begin{array}{l}+ \\
+ \\
\end{array}$ \\
\hline Talassiosira & Talassiosira incerta & + & + & & + \\
\hline Thalassionema & Thalassionema nitzschiodes & + & + & + & + \\
\hline 20 & 39 & 22 & 24 & 12 & 28 \\
\hline
\end{tabular}

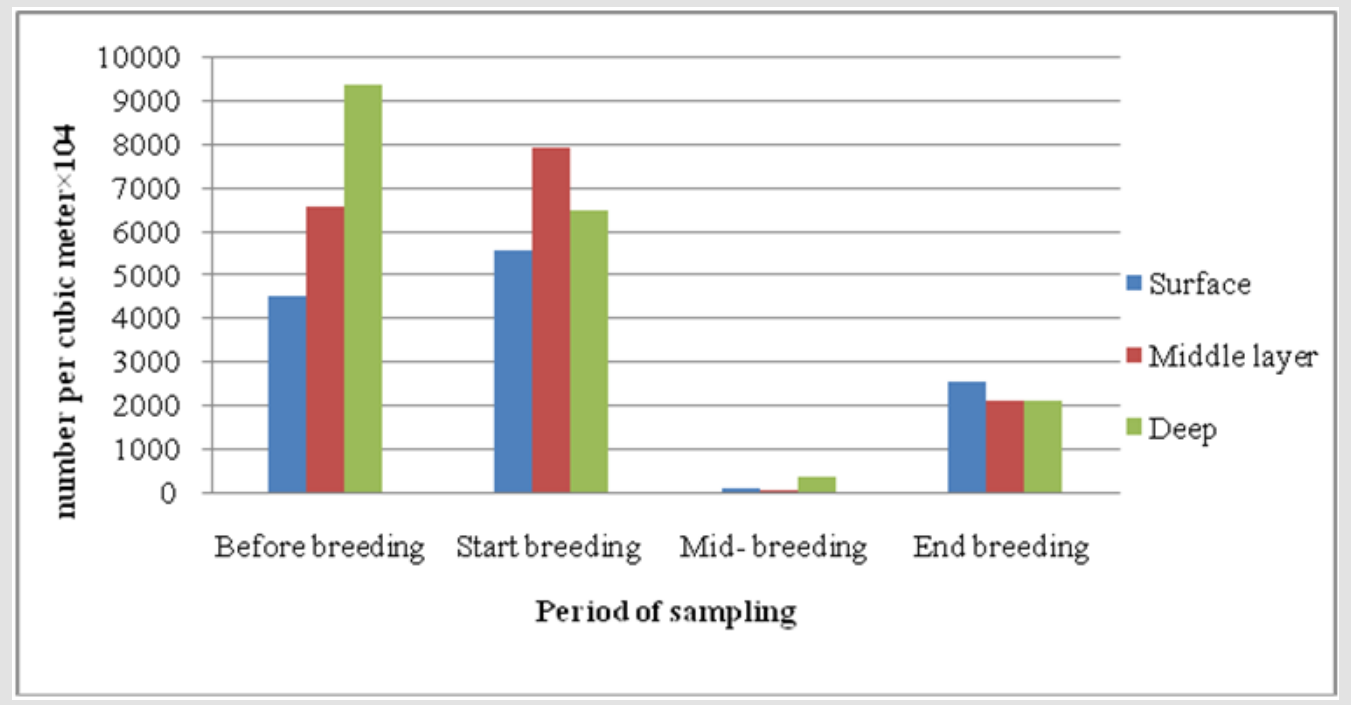

Figure 2: Density (number per cubic meter $\times 10^{4}$ ) of diatoms at different levels in different sampling periods 


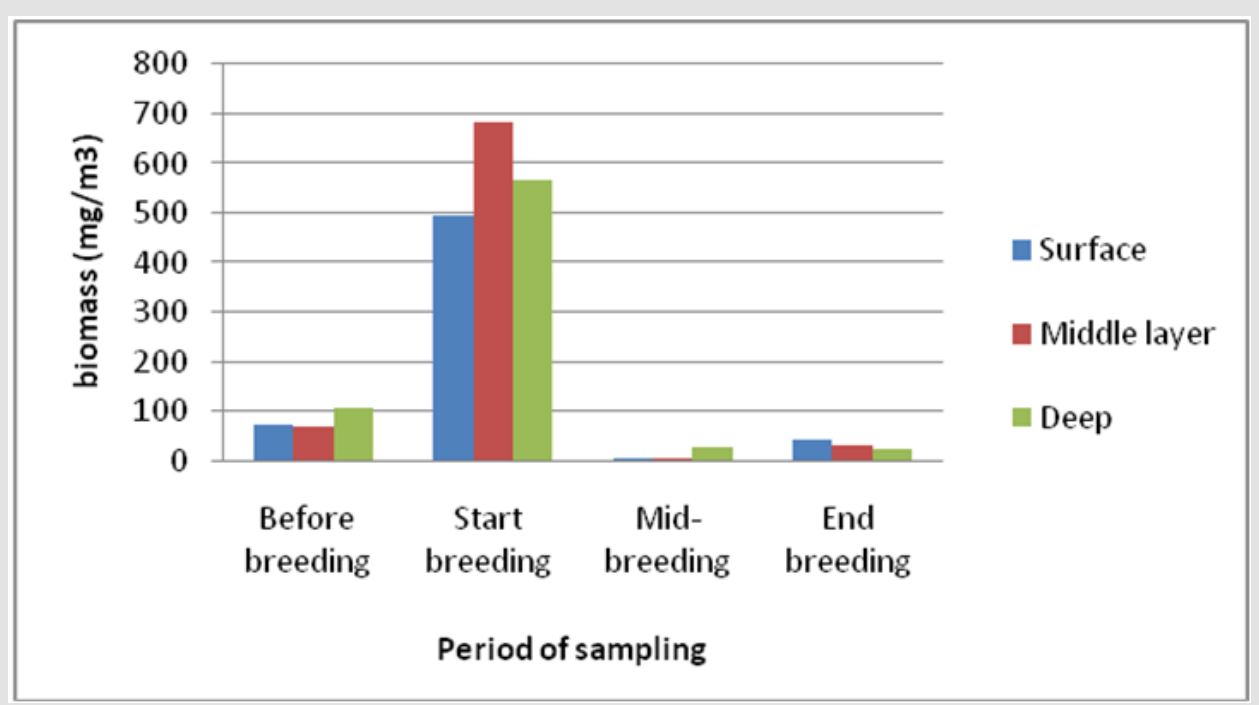

Figure 3: Biomass $\left(\mathrm{mg} / \mathrm{m}^{3}\right)$ of diatoms at different levels in different sampling periods.

Table 1: Density (number per cubic meter $\left.\times 10^{4}\right)$ and biomass $\left(\mathrm{mg} / \mathrm{m}^{3}\right)$ of diatoms in four different sampling directions in different sampling.

\begin{tabular}{|c|c|c|c|c|c|}
\hline Period of Sampling & Density/ Biomass & North & East & South & West \\
\hline \multirow{2}{*}{$\begin{array}{c}\text { Before the breeding } \\
\text { period }\end{array}$} & Density & $8454 \pm 638$ & $4585 \pm 2736$ & $4416 \pm 2228$ & $9747 \pm 1562$ \\
\hline & Biomass & $108 \pm 27$ & $32 \pm 24$ & $71 \pm 65$ & $117 \pm 3$ \\
\hline \multirow{2}{*}{$\begin{array}{l}\text { Start of the breeding } \\
\text { period }\end{array}$} & Density & $5186 \pm 586$ & $9454-864$ & $8070 \pm 301$ & $3816 \pm 791$ \\
\hline & Biomass & $506 \pm 229$ & $792 \pm 123$ & $682 \pm 117$ & $339 \pm 87$ \\
\hline \multirow{2}{*}{ Mid- breeding period } & Density & $64 \pm 33$ & $131 \pm 56$ & $181 \pm 97$ & $281 \pm 134$ \\
\hline & Biomass & $5 \pm 0.8$ & $1 \pm 5$ & $13 \pm 5$ & $16 \pm 4$ \\
\hline \multirow{2}{*}{ End of breeding period } & Density & $1584 \pm 1503$ & $3609 \pm 1284$ & $1436 \pm 625$ & 2204 \\
\hline & Biomass & $26 \pm 25$ & $45 \pm 27$ & $27 \pm 7$ & $25 \pm 13$ \\
\hline
\end{tabular}

\section{Discussion}

In this study, a total of 39 species of 20 genera of diatoms were identified during the sampling performed during four periods which include Actinocyclus(2 species), Chaetoceros (5 species), Cocconeis (1 species), Coscinodiscus (3 species), Cyclotella (1 species), Cymbella (1 species), Dactyliosolen (1 species), Diatoma (1 species), Diploneis (1 species), Gyrosigma (3 species), Hantzschia (1 species), Hyalodiscus (1 species), Navicula (3 species), Nitzschia (7 species), Pseudonitzschia (1 species), Pleurosigma (1 species), Rhizosolenia (2 species), Skeletonema (2 species), Talassiosira (1 species), Thalassionema (1 species) that the largest genus is Nitzschia; and then the genera Chaetoceros, Navicula and Actinocyclos are very common genera with many species $[10,11]$. Similar results have been obtained in other studies. Panahy Mirzahasanlou, et al. [12] introduced the largest genera, Nitzscha, Navicula, and Gomphonema, respectively, in a study on the diatoms of the Balichlu River. Studies have shown that diatom communities are usually dominated by a small number of species, with a large number of species rarely present, sometimes present, or found only once or in a single specimen $[13,14]$. Diatomaceous population structure and specific susceptibility of some species may be related to the degree of water quality. The abundance of certain diatom species can be used as biomarkers for water pollution and turbulence. Snell, et al. [15] believe that the health of ecosystems can be effectively determined by using organisms sensitive to changes in water quality such as diatoms. Atazadeh, et al. [16] also studied the diatom communities of the Qarasu River. They observed that upstream diatom communities are quite different from downstream diatom communities. The study of diatom diversity around salmon farming cages is important as a basic study for future future management plans and to investigate the impact of cage salmon farming on the ecosystem of the southern basin of the Caspian Sea.

In this study, at the end of the breeding period, due to decreasing temperature (autumn) and growth of frost-loving diatomaceous species was observed [17] and vice versa, before the beginning of breeding, the density of this branch increased that often small species increased to So that biomass has not increased significantly in this period. Diatoms play a major in primary production in the South Coast ecosystem of the Caspian Sea and are affected by environmental conditions [8] and in these studies it was shown that diatoms are affected by environmental conditions. 
Stevenson [18] classifies those environmental factors that affect the composition of diatom communities into two categories. The species composition of diatom communities is directly related to environmental factors. Another advantage of diatoms is their ease of use as a monitoring tool. Diatoms are highly diverse and abundant in aquatic ecosystems, and diatoms respond very well to macrophytes, benthic invertebrates, and fish against organic and inorganic water pollution. Therefore, researchers have identified diatoms as the best and most efficient monitoring tool for aquatic ecosystems. The Density, Biomass and number of species of diatoms observed in different breeding periods was different $(\mathrm{P}<0.05)$ and also the highest density before and in the deep layer was due to low water temperature, which is due to the cold-loving nature of this branch $(\mathrm{P}<0.05)$.

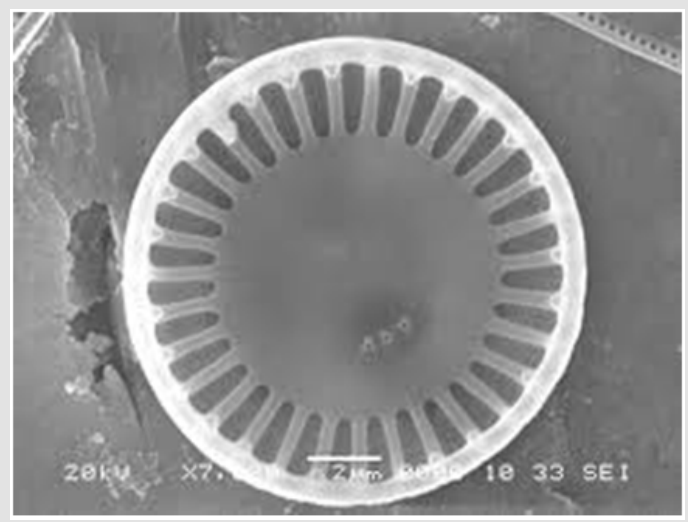

Figure 4: Cyclotella mnengiana. www.blogspot.com

Seasonal changes in various forms such as the effect on air temperature, river inflows and consequently increase nutrients, water flows and consequently salinity changes in river inflows and decrease salinity can have important effects on the population change of diatoms [19]. In this study, Cyclotella mnengiana was observed in all sampling periods and so Cyclotella mnengiana often found in oligotrophic environments, both marine and fresh water ecosystems. They are most often found in freshwater environments, but can also be found in brackish and marine habitats found in aquatic environments that are either slightly or highly alkaline such as the southern basin of the Caspian Sea (Figure 4). Another one of the species observed in this study, was Pseudo-nitzschia seriata which contains domic acid. These studies have shown that diatoms are affected by environmental condition and that Pseudo-nitzschia seriata can be dangeruse to aquatic animals (Figure 5). While the lowest density was in the middle of the rearing period, which may be due to the impact of salmon farming ecosystems in cages. Trophic and low production levels are low in the Caspian Sea. There are two water rotations in the south Caspian Sea, the first one covers the northeastern waters of Sefidrood cape, the general movement of water rotation in this area is towards the shore, where the flow part becomes two eastern and western branches (in the direction of the hands for this reason, the current extends in the western part of the cape in the west direction and in the east of the Sefidrud cape in the east direction to Mahmood Abad and Babolsar regions and a current is formed which is in the opposite direction to the east current.

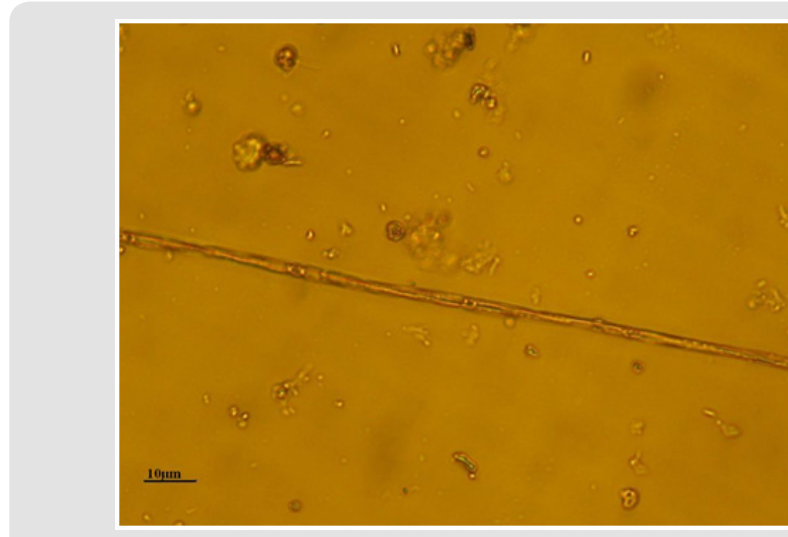

Figure 5: Pseudo-nitzschia seriata.

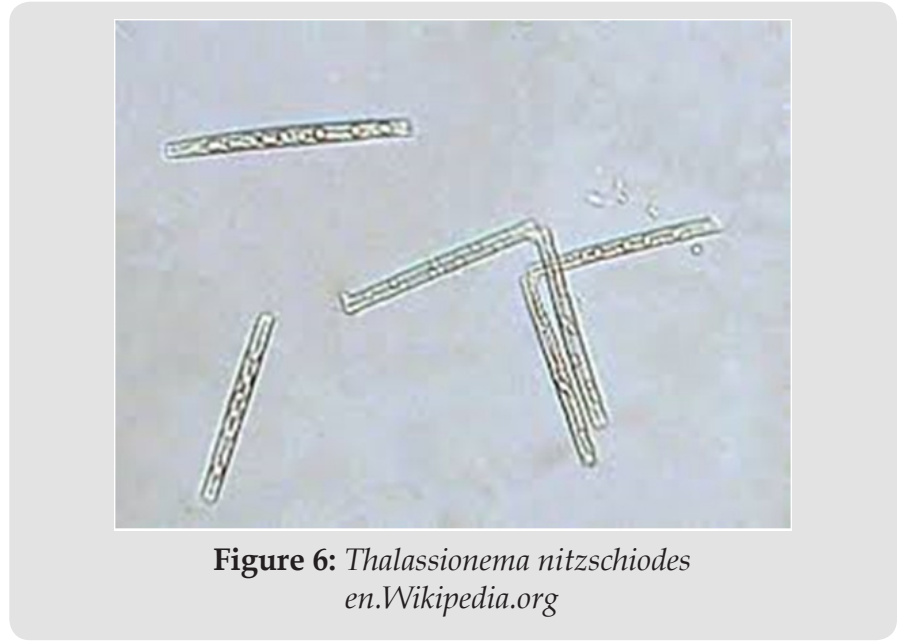

In this study, Thalassionema nitzschiodes species was also observed in all sampling periods. Cells in Thalassionema nitzschiodes are usually in star-shaped or zigzagged chains connected by mucilage pads on the ends of valves. Cells are rectangular in girdle view, with valve ends that are similar in shape and width, and are narrowly elliptical in valve view. Chloroplasts are small and numerous [20]. Cells are yellow-brown in colour [21]. Each valve has two labiate processes, one on each end; a small apical spine is sometimes also present [20]. "Marginal areolae are visible as ribs with LM. The sternum is broad and without areolae. Internally, each valve pole has a simple, slit-like labiate process, which appears externally as a small, round hole (visible with SEM)" [22] (Figure 6). This current is cut off from the shore to the northeast. At this time, the current shifts in a clockwise direction to the east and the rotation current intensifies according to the clockwise movement to the west, and at this point, the Cape Sefidrud creates an eastern current and on the 
east side of the nose, the ring is created not counterclockwise. This ring appears as isotromic and isohaline rings in different seasons of the year. These main indicators of water rotation in all seasons indicate the absence of significant differences. It is in the movement of water [23]. In late spring and early summer, nutrients enter the sea though rivers. The presence of dams in rivers (especially the Volga) reduces the entry of these nutrients into the sea [24].

In the years before fish farming in cages, the majority of phytoplankton in the south shore of the Caspian Sea consisted of diatoms, which played a major role in primary production in the ecosystem of the south shore of the Caspian Sea [25], which can be seen in this study. However, in different periods of fish farming in cages is different, which can be related to changes in air temperature and changes in nutrients, as well as the amount of nitrogen and phosphorus in the environment [26]. Due to its strategic location, the Caspian Sea has special conditions. Diatoms are an important group in the waters of the southern basin, so to make management decisions and monitor ecosystems to protect and rehabilitate them against global change and to fully understand the effects of fish farming in cages are necessary to identify diatoms and in general, according to the results obtained, the difference in the population density of the total diatoms depends on the physico-chemical conditions of water, the amount of organic matter and their distribution and density that can Due to the high nutrition of breeders [27-32]. However, it is very difficult to find the cause of all these differences and determine the factors affecting their growth. However, successful cage farming requires proper water management around caged fish, as any changes in the cage's environmental communities can affect fish, as well as any management problems in cage farming can affect the marine ecosystem. Caspian is effective and also the way of feeding and collecting waste requires a lot of care so as not to increase the organic matter of the environment.

\section{References}

1. Tahami FS, Mazlan AG, Negarestan H, Najafpour Sh, Lotfi WWM, et al. (2012) Phytoplankton Combination in the Southern Part of Caspian Sea. World Applied Sciences Journal 16(1): 99-105.

2. Draganov S, Georgiev B, Mileva E, Georgieva I (1984) Blue-green algae of the northern and central parts of the Bulgarian Black Sea coast. Hydrobiology 20: 51-64.

3. Patrick R (1961) A study of the numbers and kinds of species found in rivers of the Eastern United States. Pro-ceedings of the Academy of Natural Sciences of Philadelphia 113(1961): 215-258.

4. Rott E (1991) Methodological aspects and perspectives in the use of periphyton for monitoring and protecting rivers. In: Rott E (Eds.)., Use of Algae for Monitoring Rivers, p. 9-16.

5. Newell GE, RC Newell (2006) Marine plankton: a practical guide. Lymington, Hanys: Pisces Conservation.

6. Vollenweider AR (1974) A manual on methods for measuring primary production in aquatic enviromantal. Blackwell scientific Publication, Oxford London, pp. 423.
7. APHA S (2005) Standard Methods. American Public Health association. Washington, DC 2005, USA, pp. 346.

8. Desikachary TV (1958) Electron microscope study of the Diatom - wall structure. J Sci and Indust Res 11B(11): 491-500.

9. Habit RN, Penkow (1976) Algae no Floranders to see Vebgusta Fishers Verlaygiena.

10. Fourtanier E, Kociolek JP (2009) Catalogue of diatom names. California Academy of Sciences, pp. 156.

11. Spaulding SA, Lubinski DJ, Potapova M (2010) Diatoms of the United States. Bibliotheca Diatomologica, p. 61.

12. Panahy Mirzahasnlou, J, Ramezanpour Z, Nejadsattari T, Imanpour Namin J, Asri Y (2020) Temporal and spatial distribution of diatom assemblages and their relationship with environmental factors in Balikhli River (NW Iran). Ecohydrology \& Hydrobiology 20(1): 102-111.

13. Kelly MG, Whitton BA (1995) The trophic diatom index: a new index for monitoring eutrophication in rivers. Journal of Applied Phycology 7: 433-444.

14. Round FE (1993) A review and methods for the use of epilithic diatoms for detecting and monitoring changes in river water quality. HMSO Publisher London, p. 63.

15. Snell M, Barker PA, Surridge BWJ, Benskin CMH, Barber N, et al. (2019) Strong and recurring seasonality revealed within stream diatom assemblages. Scientific Reports 9(1): 3313.

16. Atazadeh I, sharifi M, Kelly MG (2007) Evaluation of the tropic diatom index for assessing water quality in River Gharasou, western Iran. Hydrobiologia 589(1): 165-173.

17. Karimian A (2016) Study of environmental conditions of breeding in rainbow trout cage (Oncorhynchusmy kiss) in Abbasabad region of the southern Caspian Sea, PhD thesis, Khorramshahr University of Marine Sciences and Technology.

18. Stevenson RJ (1997) Scale-dependent causal frameworks and the consequences of benthic algal heteroge-neity. Journal of the North American Benthological Society 16(1): 248-262.

19. P Panahy Mirzahasnlou, J Nejadsattari, T Ramezanpour, Z Imanpour Namin J, Asri Y (2018) The epilithic and epipelic diatom flora of the Balikhli River, Northwest Iran. Turkish Journal of Botany 42: 518-532.

20. Kraberg A, Baumann M, Durselen CD (2010) Coastal Phytoplankton: Photo Guide for Northern European Seas. In: Kraberg A, Baumann M, Durselen CD (Eds.)., Verlag Friedrich Pfeil, Munchen, Germany, pp. 204.

21. Guiry MD (2011) Thalassionema nitzschioides (Grunow) Mereschkowsky, 1902. AlgaeBase, p. 78.

22. Horner RA (2002) A Taxonomic Guide to Some Common Phytoplankton. Biopress Limited 2(2): 161-162.

23. Hosseini S, A Ganjian, A Creature, A Kayhan Sani, FS Tahami, et al. (2009) Hydrology and Hydrobiology of the Southern Caspian Sea Basin. Iran Fisheries Research Institute.

24. Aladin N, Plotnikov I (2004) The Caspian Sea. Lake Basin Management Initiative Thematic Paper, p. 1- 29.

25. Tahami FS, R Pourgholam, H Nasrollahzadeh, A Makhloogh, M Yousefian, et al. (2013) Project report on the study of diversity, biomass and phytoplankton abundance in the southern Caspian Sea region. Caspian Sea Ecology Research Institute.

26. Barone R, Flores LN (1994) Phytoplankton dynamics in a shallow, hypertrophic reservoir (Lake Arancio, Scily). Hydrobiologia 289: 199214.

27. Edmondson WT (1959) Fresh water biology. In: WT Edmondson, Henry Baldwin Ward (Eds.)., John Wiley \& Sons, Inc, London, pp. 1248. 
28. Maosen H (1983) Fresh water plankton illustration. Agriculture Publishing House, p. 85.

29. Prescott GW (1962) Algae of the western great lakes area. Brown company Publishing Iowa USA, pp. 933.

30. Pontin RM (1978) A key to the fresh water planktonic and semi planktonic rotifer of the British Isles. In: Pontin RM (Eds.)., Titus Wilson and Son. Ltd, England, pp. 178.

\section{ISSN: 2574-1241}

DOI: $10.26717 /$ BJSTR.2021.35.005678

Fatemeh Sadat Tahami. Biomed J Sci \& Tech Res

(C) This work is licensed under Creative

Submission Link: https://biomedres.us/submit-manuscript.php
31. Ruttner Kollisko A (1974) Plankton Rotifers, Biology and Taxonomy stuttyart, Schwizerbart's che Ver Lagsbuchhandlang, Stuttgart 21(1): 183-184.

32. Tiffany LH, Britton ME (1971) The algae of Illinoi. In: Tiffany LH, Britton ME (Eds.)., Hanfer Publishing company, New York, USA, pp. 407.

$\begin{array}{ll}\text { BIOMEDICAL } & \text { Assets of Publishing with us } \\ \text { RESEARCHES } & \text { - Global archiving of articles } \\ \text { - Immediate, unrestricted online access } & \text { - Rigorous Peer Review Process } \\ & \text { - Authors Retain Copyrights } \\ & \end{array}$

